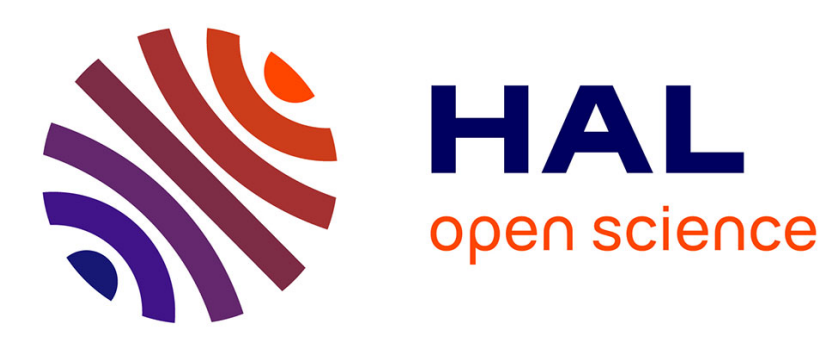

\title{
Cultural Policies and Change: Mexico and Argentina after the Neoliberal Turn (1983-2012)
}

\author{
Elodie Bordat-Chauvin
}

\section{To cite this version:}

Elodie Bordat-Chauvin. Cultural Policies and Change: Mexico and Argentina after the Neoliberal Turn (1983-2012). Latin American Policy, 2016, 7 (1), pp.147-162. 10.1111/lamp.12091 . halshs01712633

\section{HAL Id: halshs-01712633 \\ https://shs.hal.science/halshs-01712633}

Submitted on 22 Oct 2018

HAL is a multi-disciplinary open access archive for the deposit and dissemination of scientific research documents, whether they are published or not. The documents may come from teaching and research institutions in France or abroad, or from public or private research centers.
L'archive ouverte pluridisciplinaire HAL, est destinée au dépôt et à la diffusion de documents scientifiques de niveau recherche, publiés ou non, émanant des établissements d'enseignement et de recherche français ou étrangers, des laboratoires publics ou privés. 
Cultural Policies and Change

Cultural Policies and Change: Mexico and Argentina after the Neoliberal Turn (1983-2012)

Elodie Bordat-Chauvin

Latin American Policy, issue 7.1.

This article examines the changes that neoliberalism brought to the Mexican and Argentine cultural policies. Did the neoliberal turn of the 1980s and the deepening of the reforms in the 1990s have the same effects in both countries? The findings of this article show that neoliberalism had a greater effect on cultural policy in Mexico because, since the Miguel de La Madrid administration in 1982, all governments have deepened neoliberal policies. On the other hand, in Argentina, where cultural policy is less institutionalized and more dependent on politics, neoliberalism had a major influence in the 1990s but less so since 2003 and Néstor Kirchner's election.

Este artículo analiza las consecuencias del neoliberalismo en las políticas culturales mexicanas y argentinas. ¿El giro neoliberal de la década de 1980 y la intensificación de las reformas en la década de 1990 han tenido los mismos efectos en los dos países? Las conclusiones de este artículo muestran que el neoliberalismo ha tenido mayor impacto en la política cultural de México porque desde el gobierno de Miguel de la Madrid en 1982, todos los gobiernos han intensificado las políticas neoliberales. Al contrario, en Argentina, donde la política cultural es menos institucionalizada y más dependiente de la política, el neoliberalismo tuvo más consecuencias en la década de 1900, pero menos a partir de 2003 y la elección de Néstor Kirchner.

Key words: institutional change, public policies, cultural policies, Mexico, Argentina

\section{Introduction}

A comparison of Mexico and Argentina provides an interesting case for understanding the changes that neoliberalism has brought to culture. These two countries have in common the 
Cultural Policies and Change

implementation in the 1990s of the most-drastic and orthodox monetarist reforms in Latin America, and were considered to be the two best pupils of International Monetary Fund (IMF). They also share a common a history (both were Spanish colonies that became independent in 1810), and political and economic features (both are federal republics and presidential regimes and have bicameral congresses). They are members of the Group of Twenty (G-20), the World Trade Organization (WTO), and regional free-trade zones (the North American Free Trade Agreement-NAFTA—, and the Southern Common MarketMercosur). Finally, they share territorial characteristics, as they are the biggest countries in Latin America after Brazil. They also have differences that make the comparison heuristic. Mexico has a large indigenous population (6\%, according to INEGI, 2014); and in Argentina the indigenous represent only 1\% (INDEC, 2014), yet the country received 6 million foreigners between the end of the $19^{\text {th }}$ and the beginning of the $20^{\text {th }}$ centuries (Rouquié, 1978, p. 24). After the 2001 socioeconomic crisis, the Argentines elected on three occasions leftwing governments that distanced themselves from the neoliberal policies implemented in the 2000s. By contrast, in Mexico the governments of the National Action Party (PAN) deepened neoliberal reforms after they replaced the Institutional Revolution Party (PRI) in 2000.

A cultural policy can be defined as, "the actions that a state [...] take(s) that affect the cultural life of its citizens" (Mulcahy, 2006, p. 267), and also "a moment of convergence and coherence between, on the one hand, representations of the role the state may allot to art and 'culture' with regard to society and, on the other, the organization of a public action" (Urfalino, 2004, p. 13). Mexican and Argentine cultural policies share several characteristics.

1. Administrative level. Historically, the department dedicated to support culture has the same administrative-level secretariat of state, the Secretariat of Culture of the Nation in Argentina, and the National Council for Culture and Arts in Mexico. ${ }^{\mathrm{i}}$ 
Cultural Policies and Change

2. Institutional framework. Both constitutions guarantee the right to culture; there are cinema, heritage, book, and reading laws.

3. Policy Instruments. There are national funds for arts (FNA in Argentina) and culture (FONCA in Mexico).

These policies also have some differences.

1. Administrative belonging. The cultural sector was attached to education from 1921 to 2015 in Mexico. In Argentina, culture was attached to the presidency, education, and justice and linked to communication, sport, or tourism-depending on the government in power-until 2014.

2. Budget. The budgets have been historically higher in Mexico than in Argentina, as the article will show.

This article argues that neoliberalism has brought changes to the Mexican and Argentine cultural policies. Neoliberalism is understood as the sum of theories that have renewed liberal economic thinking since the end of the 1930s. These theories criticize state interventionism, which tends to limit the market and individual freedom and to cause a slowdown in economic development (Nay, 2011). Neoliberalism is at once a dominant economic theory, a political ideology, a public-policy philosophy, and a set of beliefs and mental representations (Hall \& Lamont, 2013). It is "A vague idea, a belief in the efficacy of the market, which reincarnates itself in different ways according to the political processes and the public policy sector analyzed" (Crespy \& Ravinet , 2014). If neoliberalism has brought change to the cultural policies studied here, can it be said that the scope of these changes is similar? This article will show that neoliberalism had a greater effect on cultural policy in Mexico because, since the de La Madrid administration in 1982, all governments have deepened neoliberal policies. On the other hand, in Argentina, as cultural policy is less institutionalized ${ }^{\mathrm{ii}}$ and more dependent on 
Cultural Policies and Change

politics, neoliberalism had major influence during the Menem administration (1989-99) but less so during the Alfonsín (1983-89) and Kirchner (2003-12) administrations.

Mexico and Argentina's governments reduced the scope of their cultural administration and transferred competencies to the private sector through public-private partnerships. These changes led to transformations in the cultural policies' main objectives, or "philosophy of action" (Urfalino, 2004), but in Mexico cultural policy has known more drastic changes. NAFTA induced deeper transformations in the Mexican cultural sector than did Mercosur in Argentina. Also, decentralization policies in Mexico have gone further, and the philosophy of action of "culture as an economic resource" has been dominant since the 1990s. This article shows that in Argentina a new philosophy of action appeared during Néstor Kirchner's government in 2003.

\section{Accounting for Change in Public and Cultural Policies}

Instead of explaining their transformation, scholars who study cultural policies are more inclined to describe models or trajectories (Hillman-Chartrand \& McCaughey, 1989), to analyze institutionalization processes (Dubois \& Négrier, 1999), or to describe current cultural policies through their genesis (Dubois, 1999). The few works dealing with the phenomena of change in cultural policy (Mulcahy, 1995; Paquette \& Redaelli, 2015; Gray, 2000) do not use the literature on public-policy change or are based on sectoral cultural policies, such as Surel (1997), on the book policy in France; Parker and Parenta (2009), on the cinema policy in Australia; and Shockley and McNeely (2009), on the art policy in the United States. Even though recent works attempt to fill this gap in the literature (Bordat-Chauvin \& Teillet, 2014; Barbieri, 2014), cultural policies are still unmapped territories for scholars working on public-policy changes. Gattinger and Saint-Pierre (2010) explore the consequences of the neoliberal turn in Canada by comparing two provincial cultural policies 
Cultural Policies and Change

and conclude that Ontario and Quebec have "progressively grafted economic market-based objectives into their existing policy frameworks." This article will show that the Mexican and Argentine policies present similar factors.

The literature on public-policy change shows that political scientists have studied the mechanisms of inertia and path dependence (Pierson, 2004) more than the transformation processes (Capano \& Howlett, 2009). According to Zimmer and Toepler (1996), cultural policies are particularly marked by inertia. Learning costs are very high in this sector, so changes are rare and are often considered marginal accidents that result from exogenous shocks, such as economic crises (Baumgartner \& Jones, 1991). According to Thelen (2003), elements of inertia are mixed with elements of change that allow institutions to be compatible with the changing economic, political, and social contexts. If exogenous shocks can explain changes to public policies, little endogenous changes matter too. Even if they seem marginal or invisible, they can lead to important transformations by effect of accumulation (Mahoney \& Thelen, 2010). This article argues that institutional change can be understood only by taking socioeconomic and political context and its characteristics into account, and that the degree of institutionalization of policies explains the permeability of the policy to major or minor political changes.

\section{Similar Changes that Neoliberalism Has Brought to the Cultural Policies}

In the neoliberal ideology, government should be small, and the private sector and civil society should have a greater involvement in programs. Mexican and Argentine governments reduced the scope of the cultural public sector and transferred competences to the private sector. These kinds of changes have contributed to transform the "philosophies of action" iii of both cultural policies.

\section{Reducing Administration and Budget in Culture}


Cultural Policies and Change

In both countries, New Public Management methods were implemented that induced budgetary rationalizations and suppressions of administrative structures and of public positions. These managerial discourses were coupled with the discourse of "good governance." In this perspective, reducing administrative burden allows for more-efficient and less-expensive policies and proximity with users. In Argentina, the cultural administrations were reduced from the 1990s to the mid-2000s. The Secretariat for Culture, which includes Communication since 1987, became an Under-Secretariat for Culture in 1993. On several occasions, the organization lost under-secretariats, going from three (for culture, communication, and coordination), to one (1999), or two (2001). Several national directions were suppressed or merged. National institutions, such as the National Commission for Museum, Monuments and Historic Places, became administrative delegations, functioning with the administrative autarchy principle, which implies that they depend on the Secretariat for Culture but have their own estate (made up of donations, legacies, and public funds). Other institutions - such as the Cervantes National Theatre, the National Library, and the Commission for the Protection of Popular Libraries - increased their managerial and financial autonomy, which, as Secretary of Culture Pacho O’Donnell explained, enabled them "to have freedom in managing resources, giving them the possibility of signing partnership agreements and raising funds" (P. O’Donnell, personal communication, July 6, 2010). As neoliberal policies were deepened or economic crises arose, the cultural administration was reduced.

In Mexico, since the creation of the National Council for Culture and Art (CONACULTA) in 1988, during Carlos Salinas' government, there has been a multiplication of departments and cultural organizations. This president looked for the support of the artists and intellectuals, since his election led to questions about his legitimacy in power (Bordat, 2013). From 2000, and especially from 2006 to 2012, PAN governments suppressed several cultural services. For instance, during Vicente Fox's government (2000-06), five departments were suppressed, ${ }^{\text {iv }}$ 
Cultural Policies and Change

and others lost their level in the hierarchy. ${ }^{\vee}$ During Felipe Calderón's government (2006-12), 12 departments and coordinations passed to a lower administrative level, ${ }^{\mathrm{vi}}$ as the analysis of the documents of the Federal Regulatory Improvement Commission (COFEMER) shows (COFEMER, n.d.). As with the administration, the budgets were reduced in the 1990s.

Between 1989 and 2009, Argentina assigned between 0.20 and $0.31 \%$ of the state budget to this sector. In 2001, budgets were reduced by $90 \%$. In Mexico, cultural budgets were higher. The part of the national budget fluctuated between 0.48 and $0.88 \%$ during the same period and reached its lowest in 1994, ${ }^{\text {vii }}$ during the "tequila effect" crisis. Budget cuts led to a decrease of state-funded activities. To continue their actions, public organizations turned to the private sector to fund projects or infrastructure works.

\section{Public-private Partnership in Culture}

The injunction to downsize the state and its attributions is based on the belief that action is more rational, efficient, and effective in the private sector. For this reason, since the early 1990s, Mexican and Argentine governments called for more participation from companies, foundations, and associations to fund cultural policy, especially in the cultural heritage sector. Mark Schuster (1997) warns against hasty generalizations about the meaning of the term "privatization" in the cultural sector, in particular concerning public-private partnerships. He asserts that the public-private dichotomy has blurred boundaries. That is why, in the realm of implementation and funding, it is often a question of mixed systems. Partnerships with companies are not always synonymous with privatization. For example, museums may delegate rubbish collection to firms subcontracted by the state. Moreover, even in museums that need no public funding the state intervenes in its role of guarantor of the law to ensure that contracts are fulfilled and consumer and workers' rights respected, or to regulate the activities of non-profit-making organizations. 
Cultural Policies and Change

The Mexican governments encouraged private-sector participation in the development of tourism, based on the importance of the participation of civil society in heritage administration and the need to reduce public expenditure. Through "public policy instruments" (Lascoumes \& Le Galès, 2007) such as concessions, private companies are now in charge of the regional development of culture and tourism. For instance, the administration and tourism development of Xcaret, an ecological and archeological site in the state of Quintana Roo, has been given to a private company. The agreement set in 1994 states that land where there are vestiges and exits to public roads remains under CONACULTA authority, and the company will deposit a low percentage of tickets sales for the next 25 years. In Argentina, public funds for museums were so low in the 1990s and 2000s that represented only enough to pay salaries (A. Castilla, Museum and Heritage Director, personal communication, June 2, 2010). Museum directors had to settle agreements with companies and trade private visits of museums or loans of paintings to pay for renovations.

The application of neoliberal policies led to public budget cuts and the development of new strategies and instruments to gather non-public funds, and to the inclusion of private actors in the cultural policy making. These changes also induced modifications in the main objectives of the policies.

\section{From "Democratization of Culture" to "Culture as an Economic Resource"}

The documents published by cultural institutions (plans, reports, and discourses), ${ }^{\text {viii }}$ public statements, and interviews with secretaries of culture allow for evaluations of the transformations in the cognitive framework, the objectives and definitions of the cultural policy. In both countries, the "democratization of culture" philosophy - that is to bring high culture, art, and artists to individuals who are not used to it — was the main philosophy during the Alfonsín administration and at the beginning of the Salinas government. When neoliberal policies deepened, a new philosophy appeared, "culture as an economic resource." In this new 
Cultural Policies and Change

philosophy, investments in culture have to generate employment and currencies and participate in the economic development.

According to the main objectives and missions of the Argentine cultural policy during the Alfonsín government, the philosophy of action was "cultural democratization" (see Table 1).

With the support of the United Nations Educational, Scientific and Cultural Organization (UNESCO), Secretary Marcos Aguinis (1986-87) implemented a program called National Program for the Democratization of Culture (PRONDEC). Its objective was to fight against authoritarianism in Argentina's society through culture. When Carlos Menem was President (1989-99), "democratization of culture" was no longer the only philosophy of action. "Culture as an economic resource" became increasingly dominant. The notions of "culture" and "economy" were closely linked, as this quote from the Federal Plan for Culture, published in 1990, shows. "[Culture] is a sort of web that connect economic, political and social domains" (Secretaría de Cultura, 1990). Culture is understood as creation, production, and merchandise. Art is no longer considered solely as carrying meaning; it is also a production, in the sense that culture creates and puts goods into circulation. The authors of the Plan underlined that, "culture should not passively wait for economic development [...] in order to benefit from it. [Culture] must participate in order to meet the market demands" (Secretaría de Cultura, 1990, p. 22). According to Secretary O’Donnell, ${ }^{\text {ix }}$ the free and massive outdoor concerts that he often organized in Buenos Aires contributed to "strengthen the social link" and democratize the access of culture, because "it includes everybody" (personal communication, June 7, 2010, Buenos Aires). All of the Secretariat for Culture's communication was oriented toward the consumption of culture. In an institutional advertising campaign, Argentines were invited to read and therefore buy books, to see art exhibitions and then buy art pieces, and so on. The role of culture as a symbolic creator was left aside for its entertaining and economic role. Secretary Pacho O'Donnell (personal 
Cultural Policies and Change

communication, July 6, 2010) underlined that cultural public organizations must sign partnerships with the private sector and make the Argentines pay for cultural services to maintain their activities and overcome the economic crisis. "Culture, he declared, should learn lobbying and stop complaining, and learn to negotiate" (Clarín, 1997).

In Mexico, when V. Flores Olea was at the head of CONACULTA (1988-92), the "objectives" of the cultural policy were clearly linked to the democratization of culture philosophy, as is shown in Table 2.

When V. Flores Olea was evicted in 1992 and replaced by Rafael Tovar y de Teresa, the philosophy of action continued to be the democratization of culture, as several programs dedicated to the diffusion of heritage, art, and popular or indigenous culture show (CONACULTA, 1990, 1995), but a new philosophy progressively appeared, "culture as an economic resource." It did not replace the democratization of culture but rather the two coexisted. In 1992, R. Tovar highlighted the fact that touristic promotion of heritage was important and that the archeological zones needed to be reinforced as generators of resources. He stressed that, to achieve this, the participation of the private sector and local government in its defense and preservation was decisive (Proceso, 1992; Tovar y de Teresa, 1994). A replacement of a political leader can be seen as a marginal factor of change, but change in decision makers can induce important transformations in public policy because the administration takes part in decisions and has leeway in their implementation (Geddes, 1994). This situation is even stronger in Mexico and Argentina, where there is a pyramidal "system of patronage" (Grindle, 2012) in public administrations that allows decision makers to ensure their subordinates' loyalty, as they can dismiss them at any moment. These changes have even more consequences when the organization's missions are not strongly and clearly defined (Selznick, 1957). Furthermore, these actors are part of the definition and construction of the organizations' identities, thanks to their capacity to appoint their teams. Replacing 
Cultural Policies and Change

administrative managers means replacing the agents authorized to talk about cultural policy and the way of talking about it. With President Zedillo (1995-2000), the "culture as an economic resource" philosophy became more important. In his Development Plan he stated that it was necessary to "encourage the contribution of the private sector" in support of the creation and diffusion of cultural products. Thanks to "the updating of cultural institutions' legal framework, social participation in the funding, planning and carrying out of projects for the conservation, promotion and diffusion of culture will be strengthened" (Presidencia de la República, 1995).

Mexico and Argentina's cultural policies have seen similar changes - a decrease in cultural budgets, suppressions of organizations, and an increasing participation of the private sector. These changes induce the emergence of a new philosophy of action-culture as an economic resource - that challenges the preexisting one, the democratization of culture. Exogenous factors have induced these changes (i.e. macroeconomic policies), but so have small endogenous changes (the appointment of new decision makers to head the cultural policies).

\section{Intermittent Changes in Argentina, Deeper Changes in Mexico}

Despite the political alternation in 2000 , there has been no shift in the Mexican economic policy. Rather the two right-wing governments of the PAN (2000-12) deepened neoliberal policies. Culture as an economic resource started to replace democratization of culture as the main philosophy of action. In Argentina on the contrary, the election of a left-wing government in 2003 led to the replacement of this philosophy for one of "social inclusion and citizenship." In addition to these differences, the instruments used to implement the objective of decentralization are different, and so are the consequences of regional free-trade agreements.

\section{Consequences of NAFTA and Mercosur for Cinema and Heritage}


Cultural Policies and Change

Exogenous factors of change do not always induce important policy transformations in all sectors and contexts. NAFTA led to significant changes in the Mexican cultural policy, especially in the cinema sector. In contrast, as the Mercosur agreement tolerates measures such as broadcasting quotas, the cinema policy did not suffer major changes. The changes in the Argentine cultural policy are to be found in the heritage sector, most affected by free-trade agreements.

One consequence of NAFTA is that Mexico has to take into account the institutional framework of the agreement and negotiate with multiple new actors, especially transnational actors, as it implements its public policies. During the negotiations with Canada and the United States, Mexico amended its legislation to prevent norms considered as protectionist by its partners from impeding the signature. This fact is visible particularly in the cinema sector. In the cinema law adopted in 1992, the quota for the transmission of national productions was reduced from $50 \%$ to $10 \%$. When NAFTA came into effect, the original measure could not be respected, as it violated the principle of free competition, the agreement's cornerstone. From then on, Mexican film production has decreased significantly. There were 104 productions in 1990, 14 in 1995, and only 9 in 1997. Approximately 90\% of the movies broadcast in Mexico come from the United States (García Canclini \& Piedras Feria, 2006, p. 28). To face this crisis, the Mexican movie industry began mobilizing and lobbying to encourage Congress to adopt a new instrument that could support the production and distribution of Mexican films. In 2002, a fund was created, financed by taxes on movie tickets ( 1 peso on each ticket, approximately $2 \%$ of the ticket price). It is known as "peso en taquilla" [peso in shop window]. Considering the earning foregone, the Motion Picture Association of America (MPAA), which includes the most-influential actors of the movie industry, demanded the annulment of this measure, considered protectionist, in January 2003. The MPAA's representative for Latin America advocated to the Mexican Supreme Court that this measure 
Cultural Policies and Change

was unconstitutional, as it went against free trade. The Supreme Court repealed the peso en taquilla measure in 2004. This example shows that NAFTA has widely reduced the Mexican state's leeway to regulate this sector and that the socioeconomic context matters to explain policy changes.

Mercosur has not led to this kind of change in Argentine cultural policy, first because the liberalization of some cultural sectors and the opening to foreign investments predate the signature of the Asunción treaty. ${ }^{\mathrm{x}}$ In this case few endogenous changes (progressive liberalization of several sectors) led by accumulation to more-important policy changes. Second, Mercosur allows countries to adopt measures that NAFTA forbids, such as quotas for broadcasting national productions or funds for the movie industry financed by a tax on movie tickets. ${ }^{\mathrm{xi}}$ Still, Mercosur led to other types of changes with the creation of new instruments, the "cultural Mercosur" label, which facilitates the circulation of cultural goods; Cultural Information System of Mercosur (SICSUR); ${ }^{x i i}$ the fund of cultural, Mercosur, ${ }^{\text {xii }}$ and recently, the Cultural Industries Market of the South (MICSUR). ${ }^{\text {xiv }}$ Mercosur also promotes the emergence of new actors, such as the Cultural Parliament of Mercosur (PARCUM). ${ }^{\mathrm{xv}}$ Mercosur fosters the formulation of new objectives (circulation of artistic works and artists, cooperation agreements in cultural sectors) and new programs, such as the Inca Trail (Qhapac Nán). ${ }^{\text {xvi }}$ Thus, Mercour has had several effects on cultural policy, new public instruments, actors, and cognitive frameworks, even if at first glance they seem less visible than in the case of Mexico and NAFTA.

\section{Implementing Decentralization}

Decentralization is an objective in both cultural policies, but it has not been implemented with the same kind of instruments ${ }^{\text {xvii }}$. Decentralization has become one of the main goals in the cultural policy objectives and missions of both countries since the 1990s because even though they are federations, Mexico and Argentina are countries where power is highly centralized, 
Cultural Policies and Change

and sub-national governments have no formal competencies in culture. Furthermore, decentralization is one of the recipes that neoliberalism promotes to downsize the state. Finally, UNESCO recommends decentralizing cultural policy to deepen democracy at a local level. In Mexico, decentralization is considered an instrument that provides cultural goods and services for the whole country (CONACULTA, 1994, p. 17). Secretary R. Tovar y de Teresa (1994) underlines that the state has "to preserve the mosaic of regional and local creation" thanks to decentralization policies (p. 75). During Vicente Fox's government (2000-06), decentralization became a synonym of citizen participation. In Argentina, decentralization is understood as reparation. According to the Federal Plan of Culture of 1990, Buenos Aires and other big cities would have captured Argentina's economic resources and imposed a way of life and development on the rest of the country (Secretaría de Cultura, 1990, p. 19). Decentralization allowed them to reverse this situation. It could be possible if every national institution of culture had a representative from each province. As in Mexico, Argentina's decentralization has been operationalized through changes in the relationship between actors and the adoption of new instruments.

Since the early 1990s, Mexico's public authorities have created institutions to transfer resources from the federation to the states and encourage coordination between both levels of government; these are the regional units of culture. Furthermore, CONACULTA supports regional cultural infrastructures co-managed and co-funded by state governments, artists, and artistic associations of states called mixed funds. It is what P. Moulinier calls a "civic decentralization," that is "the gift of cultural and social responsibilities to people involved" (2002, p. 14) to give minorities the right to express themselves. In the 2000 s, "municipal funds for culture" were created that are "economic, conventional and incentive instruments," as they rely on mechanisms of participative democracy and aim at deepening participation at every level of government (Lascoumes \& Le Galès, 2011, p. 101). Each fund includes a 
Cultural Policies and Change

'Citizens' Community' that includes representatives from each sector of civil society and the local cultural community (CONACULTA, 1995, p. 38) to "collaborate" in the planning of the national cultural policy.

In Argentina, there are no economic or financial instruments like those observed in Mexico. National budgets are much lower and cannot allow for these kinds of funding. The objective of decentralization is implemented through the creation of several institutions at which national and federal authorities are invited to discuss. The first consultation of provinces about culture happened shortly after the return of democracy, in 1984, as artists, playwrights, and writers, named at the head of the Secretariat of Culture, wanted their proposals for the cultural policy to reach a consensus. Other spaces of participation and dialogue were created in the 2000s. The De La Rúa government (1999-2001) created a "federal consultative committee" to gather regional representatives of culture, appointed by peers. During Cristina Fernández de Kichner's mandate (2007-11), the federal committee of Culture created in 1979 was put into operation. Since 2006, the Argentine Congress of Culture is organized every two years and brings together many actors from the cultural sector to share experiences and express demands regarding the cultural policy. The creation of these institutions, spaces of dialogue, and representations of provinces allowed relationships between federal and provincial institutions of cultural policy to change.

Despite an increasing number of instruments and spaces of participation for Argentine provinces and Mexican states, one cannot talk about "political and administrative cultural decentralization" (Moulinier, 2002), as CONACULTA and the Secretariat of Culture delegate only a few competencies to sub-national cultural institutions. Funds were created in Mexico, and new spaces of dialogue were created in Argentina. The same objective, decentralization, was not implemented with the same instruments. 
Cultural Policies and Change

\section{A New Philosophy of Action}

Political alternations and small endogenous changes led to changes in the philosophies of action. In Mexico, "culture as an economic resource" became progressively dominant. In Argentina, after the political alternation of 2003, "social inclusion and citizenship" replaced it.

During Secretary Sari Bermúdez's time in office (2000-06), there was tension between the democratization-of-culture and culture-as-an-economic-resource philosophies of action, as the "principles" of the cultural policy in Table 3 show.

The equal access to cultural goods and services and "balanced cultural development" clearly refers to the democratization of culture principles. The latter notion is explained in Vicente Fox's Cultural program; "art and culture are part of everyone's full development" (CONACULTA, 2001, p. 1), and "The government will support culture because of its intrinsic value as a privileged form to succeed to a development that includes political, economic and social freedom, to equal opportunities to education" (CONACULTA 2001, p 22). As for the "citizenization" [ciudadanización] of public institutions, it is an expression from the United Nations Development Programme (UNDP) jargon and refers to the inclusion of citizens in public administrations.

During Felipe Calderón's government (2006-12), one single “principle” was presented, "balanced human development," which meant "that all Mexicans have access to the participation and enjoyment of art and cultural heritage in this country as a part of their human development" (CONACULTA, 2007, p. 22). The transformation in the names and objectives in heritage departments shows that culture as an economic resource progressively became the main philosophy of action during the PAN governments. During the PRI governments, the first cultural program was "Preservation and Diffusion of National cultural Heritage." S. Bermudez kept this program and created a new one, "Heritage and Tourism 
Cultural Policies and Change

development." With Secretary Sergio Vela (2006-09), the mention of "preservation" of the first program was replaced by "Heritage and Cultural Diversity," and the second became "Culture and Tourism." Then the Heritage department started to include tourism. The representation of heritage changed from being a factor of identity to a factor of economic development. Finally, several programs were cancelled during Felipe Calderón's government, diffusion of popular (indigenous) culture, decentralization and social link, and popular participation to cultural policy. The only direction created was for cultural industries. Minor changes, which might have seemed invisible, led to the consolidation of a change in the cultural policy philosophy; democratization of culture was progressively left aside, and culture as an economic resource became the only philosophy of action.

When he arrived to the presidency, Néstor Kirchner made major changes to Argentina's macroeconomic policy and took a large step back from neoliberal institutions, especially the IMF. Secretary Torcuato Di Tella (2003-04) conducted a cultural policy that aimed to develop the "social role of art" so that "deprived groups" had cultural activities. For instance, in the Palais des Glaces, an elite cultural venue, he organized an exhibition of piquetero and cartonero art. ${ }^{\text {xviii }}$ Culture was no longer considered an economic resource but a way of reconstructing social cohesion. Even the touristic-cultural policies were oriented toward the social use of heritage (Di Tella, 2003). He resigned in 2004 and was replaced by another sociologist, José Nún. Whereas Torcuato Di Tella stressed the importance of the industrial and productive nature of culture, José Nún believed there was a need to "consolidate national identity" and "give new value to the sense of belonging to the nation" (Jefatura de Gabinete, 2007, p. 343), and that "the construction of citizenship" was a major issue. A new philosophy of action appeared, "social inclusion and citizenship." Culture was then an "expediency" (Yúdice, 2003) to reconstruct a broken social fabric. This philosophy gave meaning and coherence to such diverse objectives as financing cultural projects of worker-controlled 
Cultural Policies and Change

factories [empresas recuperadas], booking distributions to social housing inhabitants, and promoting heritage protection or programs for indigenous populations aimed at modernizing and developing craft production. Art should help social inclusion, such as in the "community development program" that participated in the financing of cultural projects that "reinforce local identity, participation and regional work" (Jefatura de Gabinete, 2007 p. 354), or the Culture Nation Coffee program that allowed for dialogue and citizen debates and repaired the damaged social fabric (Jefatura de Gabinete, 2005, pp 35, 37). These different programs seek to link culture and identity with a socioeconomic activity, with work, and therefore with social inclusion. In Argentina, the political alternation led to a transformation of the philosophy of action because the policy was less institutionalized ${ }^{\mathrm{xix}}$ and therefore more dependent on politics, but also because there had been a change in macroeconomic policies. In Mexico, as the general orientation of the policies continued to be neoliberal, there were no changes in the cultural policy philosophy of action.

\section{Conclusion}

Most Western countries have adopted similar main objectives influenced by the UNESCO reports - democratization of culture, growth of cultural industries, and professionalization of the cultural sector - and have given a growing role to the private sector, local governments, and international organizations. The philosophies of actions of Mexico and Argentina's cultural policies are similar, and this article has underlined that they have also created new ones, "culture as an economic resource" and "social inclusion and citizenship." The Kirchner administrations have taken a step back in the implementation of neoliberal policies, whereas the PAN governments in Mexico deepened these policies, so the consequences on cultural policies were different. In the 1990s, cultural budgets were low, several cultural institutions had to shut down, and cultural investments had to generate return on investments. In Mexico, 
Cultural Policies and Change

neoliberalism had broad changes since the 1990s, especially in cinema and heritage, because all four governments studied here implemented the same economic policy. The socioeconomic and political contexts are thus major factors in explaining cultural policy changes. This article has also underlined that changes that can be perceived as small, such as the dismissal of a leader in the administration, can have consequences when the organization's missions are not strongly and clearly defined. In both countries, the arrival of new decision makers has led to a transformation in the philosophy of action of the cultural policies.

\begin{abstract}
About the Author
Elodie Bordat-Chauvin holds a $\mathrm{PhD}$ in political science and an undergraduate degree in ethnology. She published the book When Cultural Policy Change. Comparing Mexico and Argentina with Peter Lang in 2015. She currently teaches comparative politics and cultural policies at the Institut d'Etudes Politiques d'Aix-en-Provence and in Aix-Marseille Université (France), and she is a researcher at the CHERPA research center.
\end{abstract}

\title{
References
}

Barbieri, N. (2014). Légitimité et changement des politiques culturelles: de la transition culturelle à la " désétatisation". Le cas de la Catalogne. Pôle Sud, 40(1), 137-152.

Baumgartner, F., \& Jones, B. (1991). Agenda Dynamics and Policy Subsystems. Journal of Politics, 53(4), 1044-1074.

Bordat-Chauvin, E. (2015). When Cultural Policies Change. Comparing Mexico and Argentina. Brussels: Peter Lang.

Bordat-Chauvin, E., \& Teillet, P. (2014). Retour sur les transformations contemporaines des politiques culturelles. Pôle Sud, 41(2), 5-16.

Bordat, E. (2013). Institutionalization and change in cultural policy: CONACULTA and cultural policy in Mexico (1988-2006). International Journal of Cultural Policy, 19(2), 222-248.

Capano G. \& Howlett M. (2009). Introduction. The Determinants of Policy Change: Advancing the Debate. Journal of Comparative Policy Analysis: Research and Practice, 11(1).

Centro de Estudios de las Finanzas Públicas. (2012). El apoyo a la cultura en Mexico. Mexico 
Cultural Policies and Change

City: Camara de Diputados.

Clarín. (1997, April 10). Dos años y medio de una gestión con mucho éxito. Retrieved December 10, 2013, from www.clarin.com

COFEMER. (n.d.). Manual de organización general del CNCA. COFEMERMIR. Retrieved March 12, 2012, from www.cofemermir.gob.mx

CONACULTA. (1990). Programa Nacional de Cultura 1990-1994. Mexico City: CONACULTA.

CONACULTA. (1994). Memorias 1989-94. Mexico City: CONACULTA.

CONACULTA. (1995). Programa Nacional de Cultura 1995-2000. Mexico City: CONACULTA.

CONACULTA. (2001). Programa Nacional de Cultura 2001-2006. Mexico City: CONACULTA.

CONACULTA. (2007). Programa Nacional de Cultura 2007-2012. Mexico City: CONACULTA.

Crespy, A., \& Ravinet P. (2014). Les avatars du néo-libéralisme dans la fabrique des politiques européennes. Gouvernement et action publique, 2(2), 9-29.

Di Tella, T. (2003). Plan Nacional quiquenal para una revolución cultural en la Argentina. Buenos Aires : Secretaría de Cultura.

Dubois, V. (1999). La politique culturelle : genèse d'une catégorie d'intervention publique. Paris: Belin.

Dubois, V. \& Négrier E. (1999). L'institutionnalisation des politiques culturelles en Europe du Sud : éléments pour une approche comparée. Pôle Sud, 10(1), 5-9.

Falleti, T. G. (2010). Decentralization and subnational politics in Latin America. New York: Cambridge University.

García Canclini, N., \& Piedras Feria, E. (2006). Las industrias culturales y el desarrollo de México. Mexico: XXI Siglo Veintiuno Editores.

Gattinger, M. Saint-Pierre, D. (2010). The "Neoliberal Turn" in Provincial Cultural Policy and Administration in Québec and Ontario: The Emergence of 'Quasi-Neoliberal' Approaches. Canadian Journal of Communication. 35, 279-302.

Geddes, B. (1994). Politician's dilemma: building state capacity in Latin America. Berkeley: University of California.

Gray, C. (2000). The Politics of the Arts in Britain. Basingstoke: Macmillan.

Grindle, M. (2012). Jobs for the Boys, Patronage and the State in Comparative Perspective.

Cambridge: Harvard University.

Hall, P. A., \& Lamont, M. (2013). Social resilience in the neoliberal era. Cambridge: Cambridge University.

Hillman-Chartrand, H., \& McCaughey, C. (1989). The Arm's Length Principle and the Arts: An International Perspective - Past, Present and Future. In Cummings. M.C., Schuster, J.M. (eds). Who's to Pay for the Arts? The International Search for Models of Support (pp. 43-80). New York: ACA Book.

INDEC. (2014). INEGI. Encuesta complementaria de los Pueblos Indígenas. Retrieved February 13, 2014, from www.indec.mecon.ar

INEGI. (2014). INEGI. Panorama Sociodemográfico de México, censo 2010. Retrieved February 13, 2014, from www.cuentame.inegi.org.mx

Jefatura de Gabinete. (2007). Memoria detallada del estado de la Nación. Buenos Aires: Jefatura de Gabinete del Estado de la Nación.

Jefatura de Gabinete. (2005). Memoria detallada del estado de la Nación. Buenos Aires: Jefatura de Gabinete del Estado de la Nación.Lascoumes, P. \& Le Galès, P. (2011). Introduction: Understanding Public Policy through Its Instruments-From the Nature 
Cultural Policies and Change

of Instruments to the Sociology of Public Policy Instrumentation. Governance An International Journal of Policy, Administration, and Institutions, 20(1), 1-21.

Mahoney, J., \& Thelen, K. (2010). Explaining Institutional Change: Ambiguity, Agency, and Power. Cambridge: Cambridge University.

Mercosur. (1991). Protocole de Colonia pour la promotion et la protection réciproque des investissements dans le MERCOSUR. OEA. Retrieved from www.sice.oas.org/trade/mrcsr/colonia/pcolonia_s.asp

Ministerio de Economía. (2007). Presupuesto de la administración nacional 1965-2006. Gastos por Finalidad-Función y Naturaleza Económica 1965-2006, Buenos Aires: Ministerio de Economía.

Moulinier, P. (2002). Politique culturelle et décentralisation. Paris: PUF.

Mulcahy, K. V. (2006). Cultural Policy: Definitions and Theoretical Approaches. The Journal of Arts Management, Law and Society, 35(4), 319-330.

Mulcahy, K. V. (1995). Public Culture and Political Culture: La Politique Culturelle du Québec. The Journal of Arts Management, Law and Society, 25(3), 225-249.

Murillo, M. V., \& Levistsky, S. (2010). Variación en la Fortaleza institucional, 24, 31-56.

Nay, O., (ed). (2011). Lexique de Science politique. Paris: Dalloz.

Parker, R., \& Parenta, O. (2009). Multi-level order, friction and contradiction: the evolution of Australian film industry policy. International Journal of Cultural Policy, 15(1), 91105.

Paquette, J. Redaelli, E. (2015). Arts Management and Cultural Policy Research. New York: Palgrave Macmillan.

Pierson, P. (2004), Politics in time, History, Institutions, and Social Analysis, Princeton and Oxford: Princeton University.

Presidencia de la República. (2012). Sexto Informe de gobierno de Calderon. Mexico: Presidencia de la República.

Presidencia de la República. (2000). Primer Informe de gobierno de Fox. Mexico: Presidencia de la República.

Presidencia de la República. (1995). Primer Informe de gobierno de Zedillo. Mexico: Presidencia de la República.

Proceso. (1992, October 26). La iniciativa privada tendría que completar el presupuesto que otorgó Salinas al nuevo INAH. Proceso, retrieved March 13, 2013, from

www.proceso.com.mx/

Rouquié, A. (1978). Pouvoir militaire et société politique en République argentine. Paris: Fondation Nationale des Sciences Politiques.

Secretaría de Cultura. (1990). Plan federal de Cultura. Buenos Aires: Secretaría de Cultura.

Secretaría de Cultura. (1984). Plan Nacional de Cultura 1984-1989. Buenos Aires: Secretaría de Cultura.

Selznick, P. (1957). Leadership in administration: a sociological interpretation. Evanston: Row, Peterson.

Shockley, G., \& McNeely, C. L. (2009). A Seismic Shift in U.S. Federal Arts Policy: A Tale of Organizational Challenge and Controversy in the 1990s. The Journal of Arts Management, Law, and Society, 39(1), 7-23.

Schuster, M. (1997). Deconstructing a Tower of Babel: privatization, decentralization and devolution as ideas in good currency in cultural policy. Voluntas, 8(3), 261-282.

Surel, Y. (1997). L'Etat et le livre: Les politiques publiques du livre en France (1957-1993). Paris: Editions L'Harmattan.

Thelen, K. (2003). Comment les institutions évoluent, perspectives de l'analyse comparée 
Cultural Policies and Change

historique. L'Année de la régulation, (7), 13-44.

Tovar y de Teresa, R. (1994). Modernización y política cultural. Mexico: Fondo de Cultura Económica.

Urfalino, P. (2004). L'invention de la politique culturelle. Paris: La Documentation française. Yúdice, G. (2003). The expediency of culture: Uses of culture in the global era. Durham: Duke University.

Zimmer A. \& Toepler, S., A. (1996). The subsidized muse: Government and the arts in Western Europe and the United States. Journal of Cultural Economics, 26(3), 167193.

\section{Notes} i They have had cabinet-level departments since 2014 in Argentina and 2015 since in Mexico.
ii Murillo and Levistky (2010) have shown that Argentina is a weak institutional environment.
iii A cultural policy philosophy of action corresponds to "a 'problematisation' or the way that this public policy is
built and intellectually and practically grasped" (Urfalino, 2004, p. 14).

${ }^{i v}$ The Department of Social Cohesion and Citizenization absorbed the National Coordinations for Regional Cultural Development, Cultural Activities and Cultural Development for Children (created in 1995). The National Commission on the Preservation of Cultural Heritage and the National Committee for Audiovisual Media (former unit of special projects) were suppressed. These changes took effect on the August 16, 2004.

${ }^{v}$ National committees became simple departments included in the CONACULTA's organizational chart (the Image Centre, Hellenic Cultural Centre, and the Mexican Library).

vi The FONCA's directorate general was transferred to the Secretariat of the Presidency, as was the Strategy and Prospective National Committee (which became the National Institutional Development Committee), and the Directorate General of Social Communication. The National Commission for the Preservation of Railway Heritage became part of the Directorate of Cultural Heritage Sites and Monuments. The Directorate of Cultural Cohesion was made dependent on the Cultural and Artistic Secretariat and absorbed the National Commission Cultural Heritage and Tourism, the National Commission Children's Cultural Development, the National System of Musical Development, and the Commission on Support for Music. The Directorate of Culture and Tourism created by Vicente Fox lost its rank of directorate. The Directorate General of Administration absorbed the Commission on Innovation and Quality and the Directorate General of Work Relations. Finally, the Directorate General of the Hellenic Cultural Centre became part of the National Center for the Arts (CENART).

${ }^{\text {vii }}$ Calculation realized on the basis of information obtained from the Ministerio de Economía (2007); Centro de Estudios de las Finanzas Públicas (2012); Presidencia de la República, (1998, p. 214), Presidencia de la República, (2000, p. 254), Presidencia de la República, (2012, p. 368). We wish to thank J. Ruíz Dueñas, C. Gimet, and J. Cabrera Delgado for their assistance in these calculations.

viii Grey literature is made of the planning of action (National Plan of Culture edited every six years in Mexico but more randomly in Argentina), of reports (organization memoirs), and of discourses of organizations published in their official communications (brochures and Web sites). Finally, we have used presidential annual reports presented in Congress (much like the State of the Union address in the United States).

${ }^{\text {ix }}$ F. O'Donnell did not publish a Plan. He rather gave interviews to the press and researchers to explain his policy.

${ }^{\mathrm{x}}$ Argentina did not ask for exemptions, contrary to its neighboring states Brazil, which excluded radio broadcasting services and telecommunications services; Paraguay, which excluded press, radio, and TV broadcasting medias; and Uruguay, which excluded telecommunications, radio, press, and audiovisual medias (Mercosur, 1991).

${ }^{x i}$ The legislation regulating cinematographic industry is one of the most proactive on the continent in terms of incentives for production and diffusion, spectators for national films, and the number of awards received for movies at international festivals.

xii Thanks to a satellite account, it evaluates the weight of culture in the economies of the continent and gathers information on member countries' cultural sectors.

xiii It finances creation, circulation, and promotion of cultural goods and services in the region.

${ }^{\mathrm{xiv}}$ It promotes the exchange of products of cultural industries. 
${ }^{\mathrm{xv}}$ It gathered members of the commissions of culture to create regional institutional frameworks allowing free circulation of cultural goods and services in the region and to organize legislators' work.

${ }^{\mathrm{xvi}}$ It is a network of 23,000 paths crossing Bolivia, Chile, Colombia, Ecuador, Peru, and Argentina. For the first time, countries jointly asked for the UNESCO cultural heritage of all mankind status.

${ }^{x v i i}$ For elements on the trajectories of decentralization processes and their outcomes in Argentina and Mexico see Falleti (2010).

xviii Piqueteros comes from piquete (picket), to protest by standing or walking; these movements appeared during Carlos Menem's first government. Cartoneros are kinds of rag-and-bone men who collected cardboard products to sell to firms for recycling.

${ }^{x i x}$ Even though budgets increased, a planning of the action was carried out, and an organization dedicated to culture existed, Argentine cultural policy was less institutionalized than in Mexico, which had a consolidated clientele around cultural organizations, a higher budget, and more political support during PRI administrations (Bordat-Chauvin, 2015). 